Three Theories of Augustan Waste

Andrew Cade Barrow

Fayetteville, Georgia

Bachelor of Arts, University of West Georgia, 2015

A Thesis presented to the Graduate Faculty

Of the University of Virginia in Candidacy for the Degree of Master of Arts

Department of English

University of Virginia

December, 2017 


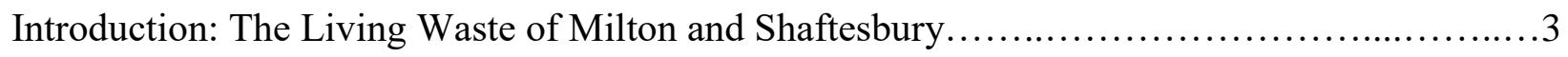

Chapter 1: Addison's Remedies......................................................11

Chapter 2: Swift's Quarantine..........................................................24

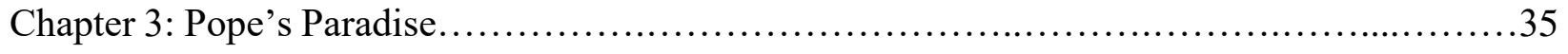

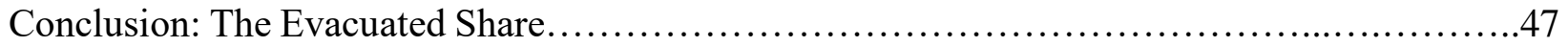

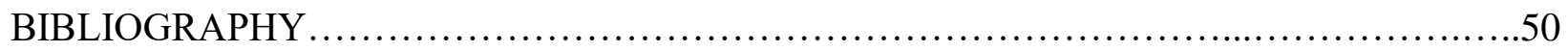


The Living Waste of Milton and Shaftesbury

Originally written in 1644 with the sole purpose of persuading Parliament to abolish prepublication licensing, Milton's Areopagitica proved surprisingly popular in the eighteenthcentury, going through several stand-alone editions throughout the period. ${ }^{1}$ In particular, Milton's famous description of printed works as "not absolutely dead things," but the "season'd life of a man preserv'd and stor'd up in books" strongly cohered with the dominant opinions of a literary culture steeped in questions of poetic production, labor, and the effects of literature on its readers. Milton's metaphor (if not his actual argument) ${ }^{2}$ offered one possible resolution to eighteenth-century anxieties of production in suggesting that even seemingly poor or debased works contain the potential to reveal "the Image of God" to readers with open minds and clear hearts: "to the pure," he echoes St. Paul in affirming, "all things are pure."3

Areopagitica's description of literary production collapses together and applies to print two senses of waste or excess familiar to Early Modern readers: for Milton, books are both those "leftovers" of moral and intellectual growth not pruned away in the process of publication, and the fertile "wasteland" in which new ideas grow uncultivated. ${ }^{4}$ If, as Sophie Gee describes,

\footnotetext{
${ }^{1}$ For a detailed eighteenth-century reception history of Areopagitica, see Erik L. Johnson, "'Life Beyond Life': Reading Milton's Areopagitica through Enlightenment Vitalism," EighteenthCentury Studies 49, no. 3 (Spring 2016): 353-70.

${ }^{2}$ Infamously, Milton excludes books of "tolerated Popery and open superstition" from his call for freedom from licensing, on the basis that such works are incompatible with the republic of "brotherly dissimilitudes" he envisions. See John Milton, Areopagitica, in Complete Poems and Major Prose, ed. Merritt Hughes (Indianapolis: Hackett, 1957), 716-49 pp. 747.

${ }^{3}$ Ibid. 720, 727.

${ }^{4}$ Put another way, Milton largely elides the distinction later made by Georges Bataille between useful excesses which "can be used for the growth of the system" and the "accursed share" which "must necessarily be lost without profit." See Georges Bataille, The Accursed Share: An Essay on General Economy, Vol. 1: Consumption, trans. Robert Hurley (Cambridge: Zone Books, 1991) pp. 21. As Denise Gigante notes, however, Milton does observe a similar distinction to Bataille's when it comes to non-literary economies: see Denise Gigante, Taste (New Haven: Yale University Press, 2005) pp. 24-31.
} 
"waste matter... was usually seen as valuable because it was a leftover: a sign that something important had happened, leaving a residue behind," there can be no more sacred matter than that which arises from publishing, that "consummate act of... fidelity and ripeness." 5

Milton sacralizes the mundane matter of print literature further when, in his defense of the edifying nature of morally dubious literature, he references the Biblical creation myth:

The knowledge of good is so involved and interwoven with the knowledge of evil, and in so many cunning resemblances hardly to be discerned... It was from out of the rind of one apple tasted, that the knowledge of good and evil, as two twins cleaving together, leaped forth into the world... As therefore to the state of man now is, what wisdom can there be to choose, what continence to forbear without the knowledge of evil? ${ }^{6}$

In these lines, Milton transforms “evil" literature from abject matter devoid of value into fertile ground for the cultivation of experienced, knowledgeable, and active virtue. In this way he aligns aesthetically deficient and morally dubious works with the unworked "wasteland" of Eden, as instances of abundance rendered morally justifiable by the introduction of labor. ${ }^{7}$ In collapsing the distinction between waste, wasteland, and print, Milton formulates a moral obligation to strike down laws which inhibit the flourishing of the print industry, and thereby prevent readers from improving and testing themselves upon the literature of others.

Such arguments were doubtlessly on the minds of Parliament when, in 1695, they declined to renew the Printing Acts against which Areopagitica was written, theoretically freeing up the business of print and allowing Milton's nationwide repatriation of print waste to occur.

\footnotetext{
${ }^{5}$ Sophie Gee, Making Waste (Princeton University Press, 2010) pp. 4. Milton, Complete Works 758.

${ }^{6}$ Milton, Major Works pp. 778.

${ }^{7}$ For the relationship between Edenic abundance and the redeeming nature of Labor in Milton's theology see Gee, Making Waste pp. 54-62
} 
Practically speaking, the effect of these legal reforms on the book publishing industry was mild at best - modern historians have generally found that economic factors played a far greater part in the eighteenth-century expansion of printing than the lapse of the Acts ${ }^{8}$ - but this in no way diminished the popular perception that England was entering an era of printed abundance vastly different from those which came before. Addison's Spectator, Swift's A Tale of a Tub, and Pope's Dunciad all respond to this phenomenon — and all demonstrate a profound uneasiness or outright disgust with the easy proliferation of lived experiences and "seasoned lives" extolled by Milton.

My purpose in writing this essay consists of understanding that sense of as a product of uniquely Augustan theories of waste, taste, and value. It is my contention that the taste-makers of the Augustan era developed a rhetoric of literary exclusion both dependent upon and radically different from the Miltonic association of print, waste, and reproduction. The writings I profile each corroborate Milton's assertion that print works “contain a potency of life in them to be as active as that soul was whose progeny they are," but repurpose the implied relationship between author and work to apply to the reader, discarding the notion that the English public "art sufficient both to judge and examine" most works of literature for themselves. ${ }^{9}$ Despite this shared quality, however, Addison, Swift, and Pope substantially differ from one another in both their individual theorizations of and responses to the problem of generative bad literature unintentionally raised in Areopagitica. My interest lies in both cataloguing these responses and hinting at the manner in which their traces have resurfaced in the following centuries.

\footnotetext{
${ }^{8}$ See John Brewer, The Pleasures of the Imagination (Abingdon: Routledge, 2013) pp. 129-137 and James Raven, Publishing Business in Eighteenth-Century England (Suffolk: Boydell and Brewer, 2014) pp. 33-63.

${ }^{9}$ Milton, Major Works 720, 727
} 
Before I begin to sift through and distinguish these fragmentary theories, one final problem must be addressed: for all that Milton insists on the vitality of printed works, he grants them precious little in the way of afterlife. Whether out of distaste for the crudeness of the metaphor or concern for its implications, Milton rejects the commonplace equivalence between books and food: he acknowledges that "bad meats will scarce breed good nourishment in the healthiest concoction," but claims that "bad books... to a discreet and judicious reader serve in many respects. ${ }^{10}$ " Milton's abandonment of the gustatory metaphor unintentionally raises another question: what happens when a "false" reader gets ahold of "bad books," and what material might they produce after digesting such putrid meats?

These are the questions answered by the first book of Anthony Ashley Cooper, Earl of Shaftesbury's 1710 Soliloquy: Or, Advice to an Author, which cements Milton's expression of literature as the spiritual waste of the author and literalizes the metaphor. Conceived as a "selfdiscoursing" method designed to help men achieve their potential for sociability in private, Shaftesbury's neo-Platonic search for interpersonal perfection ${ }^{11}$ quickly takes on a rhetoric of "bodily operations": talking or writing to one's self is a "surgery" or "self-dissection," allowing authors to avoid the "indecent" act of vocally airing or (worse by far) publishing one's "crudities."12 As a metaphor for works published without sufficient consideration or care, Shaftesbury's “crudities” seem a far cry from savory Miltonic fruit—ultimately, however, Shaftesbury also treats books as products of lived experience, and attributes immense value to

\footnotetext{
${ }^{10}$ Ibid.

${ }^{11}$ Shaftesbury, Anthony Ashley Cooper. Soliloquy, or, Advice to an author (London: Printed for John Morphew, 1710) pp. 10-16. For a more thorough interrogation of the philosophy behind this self-discoursing, see Martin Price, To the Palace of Wisdom (Carbondale: Southern Illinois University Press, 1970) pp. 85-93.

${ }^{12}$ Shaftesbury, Soliloquy 7-12.
} 
the necessary aesthetic and moral labor of literary evaluation. ${ }^{13}$ The central difference between the two lies in the identity of the laborer: while Milton assumes work on the part of both the moral writer and interpreter, Shaftesbury denies that one could take a wholesome pleasure in the products of the "frothy distemper" of an essayist, and ridicules the notion that "the Reader [is] in truth any better entertained, when he is oblig'd to assist at the experimental Discussions of his of his practicing Author, who all the while is in reality doing no better than taking his Physik in public." ${ }^{14}$ For Shaftesbury, the idea of deliberately testing oneself against the undigested public "evacuations" of others is not just questionable in terms of moral value, but fundamentally debased - the ur-critic of Shaftesbury's imagined golden age "taught the Publick to discover what was just and excellent in each Performance," while only the later and "inferior Order... of Etymologists, Philologists, Grammarians" and "Rhetoricians" employed themselves in "exposing the weak sides... of mere Pretenders." "15

Shaftesbury's regime heralds the arrival of a new way of thinking about Milton's printed wastes - not only as static symbols of virtue and testing grounds for one's moral taste, but as accumulating piles of debased matter that disrupt polite exchange by their nauseating stench. Shaftesbury enlists this thoroughly unpleasant metaphor as a call to turn away from printing "crudities," but does not answer the question of how to deal with the piles that have already

\footnotetext{
${ }^{13}$ As Price notes, Shaftesbury follows Plato in upholding the dialectic as a tool for the "redirection of the soul, an awakening of the sense-bound man to the realm his mind by its nature desires to inhabit." Where Shaftesbury differs from Plato is his insistence that this act take place away from the public eye and that it be undertaken with complete liberty from didacticism and abstraction, and his association of the process of dialectic with the "self-therapy" of criticizing one's own works. See Price, To the Palace of Wisdom 97-103.

14 Ibid.

${ }^{15}$ Shaftesbury, Soliloquy 87-89. Note that Shaftesbury does not treat these classes of critic Swift's degree of contempt; while later and lesser than the ur-critic, the pedantic critics nevertheless play a valuable role in preventing flawed oration from "passing the public ear."
} 
accumulated in the public space, and now threaten to grow. For schemes of this nature, we must instead turn to the critics of the Augustan era, who responded to these accumulating street-heaps with solutions ranging from Addison's gentle crusade to cure the diseased taste of the English public, to Swift's imaginary retreat to a tasteful Utopia, to Pope's synthetic attempt to elevate the heroic poet above the chamber-pot of London's print industry—all, however, picked up on the Miltonic resonances of Shaftesbury's waste-language, noting with concern the unwholesome links between abundant wastelands and printed "crudities."

Together, the writings of these three individuals reference and constitute a new rhetoric of literary evaluation, which heaps virulent (and occasionally hyperbolic) disesteem upon certain works of print literature and their readers. I have chosen to refer to these garbage literatures as "print waste," but in doing so I do not mean to suggest that they constitute a unified genre—on the contrary, I intend "print waste" to encompass "modern" books as formally diverse as William Wotton's Reflections upon Ancient and Modern Learning and Richard Blackmore's Arthurian epics (satirized in A Tale of a Tub and The Dunciad, respectively). Although by themselves these works have little in common, they are united by the anxious rhetoric of critics who refer to them by invoking Shaftesburian "crudities," and suggest that, rather than sit inert in their abjection, these putative pieces of literary garbage teem with the virulent potential to multiply themselves.

In developing this concept, I have been deeply indebted to Sophie Gee's concept of "literary waste," her term for the used "vessels of symbolic meaning" which populate so many eighteenth-century texts. ${ }^{16}$ Like Gee's literary waste, print waste proves too abundant, too generative, and too worthless to be subsumed into conventional economies. This is why, as Gee suggests, detractors of printed waste resort so easily to sacred language to describe it: they are

${ }^{16}$ See Sophie Gee, Making Waste 4-5. 
relying on its ironic shared resonance with the religious experience as singular, and beyond value. ${ }^{17}$ In this way, discussions of print waste inevitably return to the topoi of Miltonic waste, trading simultaneously and seamlessly in metaphors of empty wastelands, the verdant wastes of Eden, and the human bodies (or, more frequently, human bodily waste) that populate those spaces.

James Noggle's The Temporality of Taste has also been exceedingly useful in this project, in particular his distinction between the categories of "taste" and "a taste"—or, the capacity of an individual to immediately "respond sensitively and discriminately to nearly anything," and the historical and social experience of predilection for a particular pleasure. ${ }^{18}$ As Noggle emphasizes, the two senses of "taste" are in theory distinct, but tend to collapse into one another in both eighteenth-century and contemporary rhetoric: one becomes an authority on taste by demonstrating one's delicacy and sensibility, which largely involved displaying the correct preferences in art and literature. ${ }^{19}$ When in his Characteristics Shaftesbury writes that "the wellbred man" and "the real philosopher" both "aspire to a just Taste," he blends these ideas in a way familiar and intelligible to the eighteenth-century: Shaftesbury's ideal man aims to both know what is good through immediate sense, and to demonstrate this knowledge to those around him.

Although hardly unusual for Shaftesbury, the masculinist tone here obviates an issue that worried Addison and delighted Pope: how does a society built on the indivisible purchase, reflection, and teaching of taste reconcile that ideology with longstanding tropes of female indulgence? Although a relatively small part of my essay, the eighteenth-century problem of

\footnotetext{
${ }^{17}$ Ibid. 14-16.

${ }^{18}$ James Noggle, The Temporality of Taste (Oxford University Press, 2012) pp. 1-3, 10-12, 1516.

${ }^{19}$ Ibid.
} 
women's tastes is emblematic of the anxieties generated by the intersection of taste and evacuation-if, as Laura Brown suggests, "the figure of the woman is the discursive means to the connection of imperialism and aesthetic theory, ${ }^{, 20}$ what happens when women outside of the Augustan poetic tradition discharge their lived experience in poetic form? Although they would hardly conceive of it in such terms, my critics' shared concern for the effects of print waste reflect a fear of cultural contamination by lived experiences of alterity—so, for example, fears of genuine or imitation chinoiserie "feminizing" English culture ${ }^{21}$ must be understood as stemming in part from an assumption that the evacuations of the female-coded Chinese self will affect the identity of those who consume them. While drawing this thread past the eighteenth century falls outside the scope of this essay, I encourage my readers to consider that the regimes of contamination which originate in these writings have survived the taste theories in which they were originally embedded — we are still, a great many insist, what we eat.

${ }^{20}$ Laura Brown, Ends of Empire (Ithaca: Cornell University Press, 1993) pp. 104

${ }^{21}$ For more on the intersections between chinoiserie and femininity in the eighteenth-century, see Jenkins Eugenia, "'Nature to Advantage Drest': Chinoiserie, Aesthetic Form, and the Poetry of Subjectivity in Pope and Swift," Eighteenth-Century Studies 43, no. 1 (Fall 2009), David Porter, The Chinese Taste in Eighteenth-Century Taste (Cambridge University Press, 2014), and Jennifer Tsien, The Bad Taste of Others (Cambridge University Press, 2014) 113. 


\section{Addison's Remedies}

Despite the close friendship and mutual sense of political affiliation between Shaftesbury and Joseph Addison, scholars of taste have met with considerable challenges in bringing the two into conversation. In large part, this difficulty originates in the vastly divergent theories of tasteas-faculty presented in Shaftesbury's Characteristics and Addison's Spectator-generally, critical consensus has it that Shaftesbury's neo-Platonic theory of the aesthetic experience as an internal "Sense of Order or Proportion" exercised over time and originating in divine final cause cannot coexist with the Addisonian conception of taste as an immediate imaginative assessment distinct from (and "more easily acquired" than) understanding. ${ }^{22}$ Of particular note, Addison significantly widens the franchise of Shaftesbury's exclusive circles of well-bred gentlemen when he both affirms that "there is nothing that makes its Way more directly to the Soul than Beauty," and acknowledges that "every different Species of sensible Creatures has its different Notions of Beauty." ${ }^{23}$ This is not, of course, to say that Addison defends relativism when it comes to taste - on the contrary, he insists that, in cases where individuals interpret words identically, "different Taste [in writing] must proceed... from the Perfection of Imagination in

${ }^{22}$ This is, of course, an extremely reductive view of the incongruities between Shaftesbury's and Addison's theories of faculty-taste. For a more complete comparison, see Timothy Costelloe, The British Aesthetic Tradition (Cambridge University Press, 2013) pp. 11-49, and Tony Brown, The Primitive, the Aesthetic, and the Savage (Minneapolis: University of Minnesota, 2012) pp. 75-80. For a more complete elucidation of the differences between aesthetic theories and taste theories, see George Dickie, The Century of Taste (Oxford University Press, 1996).

${ }^{23}$ Donald Bond, ed., The Spectator (Oxford: Clarendon, 1965) i. 412. See also Roy Porter, Flesh in the Age of Reason (New York: Norton, 2005) pp. 130-147 for an examination of Shaftesbury's opposition to egalitarian ideologies of taste. 
one more than in another" 24 _ but his conception of beauty as defined by variety does "permit an aesthetic appreciation by potentially anyone of any form." 25

The openness of this vision of an aesthetic marketplace that caters to every taste seems incongruous when considered alongside Addison's insistence that the nation's readers indulged in a "Gothic taste" for "Epigram, Turns of Wit, and forced Conceits," that its "Scriblers of Lampoons" were "very barbarous and inhuman," and that society as a whole had degenerated into a "desperate State of Vice and Folly." 26 These sentiments can only co-exist with Addison's open vision of the aesthetic marketplace because he, like Milton, recognized the intersection of valueless crud and undefined potential present in printed works — "The Mind that lies fallow but a single day," says Addison, perhaps recalling the spartoi-birthing books of Areopagitica, "sprouts up in Follies that are only to be killed by a constant and assiduous Culture." ${ }^{27}$ In that vein, the purpose of this section of my essay does not consist of reading Addison in terms of his famously free and open theory of aesthetic taste, but instead concentrating on the moments in which he restricts those freedoms, positing instead a fundamentally diseased public taste in need of a collective cure.

In contrast to their philosophical differences, Shaftesbury and Addison held extremely similar political ideologies in which taste played a key role. The works of each affirm, in accordance with standard Whiggish principles and against the appetite-driven political philosophies of Hobbes and Mandeville, that the individual pursuit of aesthetic pleasure "is

\footnotetext{
${ }^{24}$ The Spectator i. 416

${ }^{25}$ Brown, The Primitive, the Aesthetic, and the Savage 78

26 These complaints originate in The Spectator i. 409, 23, and 10, respectively.

${ }^{27}$ The Spectator i. 10. Compare to Milton's admission that "[books] are as lively and as vigorously productive as those fabulous dragon's teeth; and being sown up and down, may chance to spring up armed men" (Complete Works 720)
} 
advantageous to social affection," and therefore benefits society when enabled by a refined understanding or "polite imagination." ${ }^{28}$ This pursuit has certain caveats, however, as Addison follows Shaftesbury in insisting on the moral value of disinterested observation, ${ }^{29}$ and so remains skeptical of any foundation of aesthetic pleasure in owned land. "The Man of Polite Imagination," Addison insists, "feels a greater satisfaction in the prospect of fields and meadows than another does in the possession." ${ }^{30}$ Addison thus privileges disinterested pleasures which accrue no additional value - most often, these are the pleasures of art, live entertainment, and literature accessible to the purchasing middle-class. The result consists of nothing less than a moral imperative to purchase access to objects of aesthetic pleasure, as dictated by the polite public taste, in order to refine one's own sense of taste and better participate in the logocentric society of refined individuals - that doing so demonstrated cultural and ideological cohesion with the increasingly wealthy and politically ascendant Whigs was a mere perk. ${ }^{31}$

Fortunately for prospective men and women of taste, Whig economic theory treated wealth as an inexhaustible product of labor rather than limiting it by the availability of raw materials. ${ }^{32}$ It is for this reason, perhaps in addition to that of political conformity, that Addison views his republic of taste as a fundamentally open society where one can, by effort, train the

\footnotetext{
${ }^{28}$ Shaftesbury's Characteristics as quoted in Terry Eagleton, The Ideology of the Aesthetic (Oxford: Blackwell, 1990) pp. 37. See also Eagleton 34-37 \& 41 for a more in-depth description of the links between moral and aesthetic judgement in Shaftesbury, and The Spectator i. 411 on the polite imagination.

${ }^{29}$ See The Spectator i. 255 and Costelloe, The British Aesthetic Tradition 47.

${ }^{30}$ The Spectator i. 411. See also Carole Fabricant, "Aesthetics and the Politics of Landscape," in Studies in Eighteenth-Century British Art and Aesthetics, ed. Ralph Cohen (Los Angeles: University of California Press, 1985) pp. 49-82 for a highly-relevant discussion of Addison's "prospects" and their relationship to land ownership among the middle class.

${ }^{31}$ See James Noggle, The Temporality of Taste 17, 40-46

32 Steve Pincus, "Addison's Empire: Whig Conceptions of Empire in the Early 18th Century," Parliamentary History 31, no. 1 (February 2012): 99-117 pp. 105-110
} 
faculty of taste as surely as one can participate in the creation of wealth. May 19, 1711's Spectator, which contains a description of the London Stock Exchange as a trans-national "Emporium for the whole Earth" so beautiful that Mr. Spectator's "Heart naturally overflows with pleasure at the sight of a prosperous and happy Multitudes, ${ }^{33}$ provides a vision of the type of market utopia that Addison envisions. As Sophie Gee observes, Addison's Exchange is a "secular Eden" where all matter is both valuable and able to be converted freely and without excessive surplus through the abstract alchemy of commerce, finance and credit. ${ }^{34}$ Purchasers and sellers are present, but incidental; "the Phillipick islands give Flavour to... European bowls" of their own accords, with the dirty realities of sugar plantations abstracted away. In this utterly regular and perfectly fungible economy, the absence of waste renders the processes of Miltonic repurposing or Shaftesburian evacuation unnecessary. As we shall see, however, this regularity and financial abstraction proves the fundamental difference between trading goods and printing one's crudities - ultimately, the trace of print waste proves more materially real to Addison than the naked monetary interests of trade, and therefore distresses his conception of a self-regulating, tasteful society to a far greater degree.

Addison's project of reforming English manners was, to a large extent, inseparable from the economic project of bringing about an ideal world of free exchange. To follow Simon Gikandi's reasoning in Slavery and the Culture of Taste, cultural institutions in general and the coffeehouse in particular were financially dependent on an increasingly politically aspirant class of plantation-owners, whose "largesse... enabled the cultivation of polite conduct and the growth

\footnotetext{
${ }^{33}$ The Spectator i. 69

${ }^{34}$ Sophie Gee, Making Waste 97, 137-140
} 
in consumption that was essential to the emergence of the culture of taste." ${ }^{\prime 35}$ The arrangement was simple: "closeted colonial barons" like Christopher Codrington directly patronized Addison and other writers while indirectly supporting the tasteful enterprise through a steady stream of accumulating foreign goods, and the taste makers in turn validated and uplifted the idea of international exchange, lending it cultural capital and legitimacy. ${ }^{36}$ Addison's attempt to democratize taste and reform English society thus rests on an assumption of abstract fungibility between different types of goods and the positive effect that the private participation in those trades have upon the public—without coffee there could be no coffee-houses, and without coffee-houses there could be no Spectator. ${ }^{37}$

Of course, in reality these abstracted, fungible "goods" included not just exotic comestibles but human beings. It is striking, if not altogether surprising, that Addison, never attempted to reconcile the exceedingly non-fungible waste of the slave trade with his market system - both the literal piles of corpses capturing and transporting slaves produced and the consequent toll of human suffering are almost entirely absent from his writings. ${ }^{38}$ Instead, Addison populates his writings with panegyrics to "ships laden with the Harvest of every Climate" and "Traders of good sense" 39 — but, in a doubling that assumes paramount importance

\footnotetext{
${ }^{35}$ Simon Gikandi, Slavery and the Culture of Taste (Princeton University Press, 2014) pp. 149160

${ }^{36}$ Ibid. See also Pierre Bourdieu, Distinction, trans. Richard Nice (Cambridge: Harvard University Press, 1984) pp. 316-317.

${ }^{37}$ For the central importance of the coffee-house to both public life in general and newspapers in particular, see John Brewer, The Pleasures of the Imagination 34-40.

${ }^{38}$ Steele does recount a female friend's summary of the tragic version of the "Inkle and Yarico" story from Richard Lignon's True and Exact History of the Island of Barbadoes in The Spectator i. 11, holding up the moment in which Inkle sells his pregnant lover into slavery as an example of male cruelty. It is difficult to cite this moment as an example of Swiftian colonial awareness, however, given the "battle of the sexes across time" commonplace in which it is framed.

${ }^{39}$ The Spectator i. $2 \& 69$
} 
in Jonathan Swift's work, the human cost of Addison's tasteful reformation can never be entirely erased from its pages. When, as we shall see, print waste proves an intractable problem for Addison, and conceals beneath it a much greater issue of which he seems only dimly awarethat, in the eighteenth century, discussions of waste are impossible to separate from discussions of human worth.

April 14, 1711's issue of The Spectator, in which Addison recounts a visit to "a Lady's Library" and laments the corrupted taste and judgement of its owner, provides an example of the way in which the presence of print waste problematizes both the universally redemptive narrative of social taste and the unthreateningly generative surpluses of the Royal Exchange. ${ }^{40}$ On its surface, the essay presents a perfect model of mild Addisonian satire-our spectating narrator visits his widowed acquaintance, describes her reading and other leisure activities, and returns home to lament that she wastes her intelligence and sensitivity on meaningless French romances and other diversionary literature. He does not suggest that reading these romances is personally harmful —indeed, they are "innocent entertainments"— but nevertheless paints them in terms anticipating the morally dubious acquisitive femininity of Pope's Belinda and Swift's Vanessa: the "finely-bound and gilt" folios are paired with "Octavos bound by tea-dishes," while the juxtaposition of "A Prayer Book: with a Bottle of Hungary Water [perfume] beside" is suggestive of a wide variety of tropes linking cosmetics, femininity, luxury, and impiety. ${ }^{41}$ In describing the physical books as such, Addison suggests that Leonora's reading is excessive and

\footnotetext{
${ }^{40}$ The Spectator i. 37

${ }^{41}$ C.f. the "Puffs, Powders, Patches, Bibles, Billet-doux" of Belinda's dressing table in Alexander Pope, The Rape of the Lock, ed. Cynthia Wall (Boston: Bedford, 1997) pp. 30. Although misogynistic depictions of "feminine vanity" are common through to the classical era, they take on a new life in the early eighteenth-century as a result of the consumer revolution's foregrounding of personal economic agency: see Laura Brown, Ends of Empire 103-135 and Dustin Griffin, Pope and Swift (Cambridge University Press, 2010) pp. 62-65.
} 
useless, and he follows suit in typing Leonora as a childless widow, sequestered away from polite society "about an hundred Miles distant from London" as her "Mind naturally sinks into a kind of Lethargy, and falls asleep." 42

As a satire on poor taste, this issue of the Spectator seems at first to compliment the view of civil society indicated by the anecdote from the Exchange, as enlightened, logocentric trade by spectating men of established judgement contrasts easily with Leonora's debased, female-coded hoarding of material objects. ${ }^{43}$ As David Porter observes in The Chinese Taste in EighteenthCentury England, Addison “pointedly situates [Leonora's] taste as both occupying and corresponding to a distinct material context, consisting largely... of Chinese porcelains," thus drawing a link between frequent characterization of both porcelains and romances as having "an aesthetic of strangeness and curiosity... and a pointed lack of verisimilitude." ${ }^{44}$ Porter goes on to suggest that this linkage allows for a nationalistic satire of the supposed extravagance of feminine taste as misguided, emotional, and "debased" by foreign influence. ${ }^{45}$ Lacking the structured framework of a rigorously efficient Whig market-ideal, Leonora's bad taste transforms the "delightful pyramids" of books into dangerously excessive heaps of uncirculating waste, as toxic to her own wellbeing as the market for foreign china was to the perceived economic

${ }^{42}$ C.f. with the following passage from The Spectator i. 411 : ... [the Pleasures] of the Imagination... do not require such a Bent of Thought as is necessary to our more serious Employments, nor, at the same time, suffer the Mind to sink into that Negligence and Remissness, which are apt to accompany our more sensual Delights, but... awaken them from Sloth and Idleness, without putting them upon any Labour or Difficulty.

${ }^{43}$ Although Addison's work on taste predates the examples used by Noggle in his chapter on taste and femininity (James Noggle, The Temporality of Taste 124-150), his ruminations on the doubled nature of taste in relation to women (and the resultant misogyny of most eighteenthcentury writing on taste) are still applicable here.

${ }^{44}$ David Porter, The Chinese Taste in Eighteenth-Century Taste 57-58.

45 Ibid. 
competitiveness of English goods. ${ }^{46}$ In Miltonic terms, Leonora's books and porcelains are the waste of Chaos—not merely surplus, but an excess of perverted potential.

While Porter's assessment of the essay highlights the role of the material object in contributing to Addison's satire of the perniciously foreign romantic taste, it does not explain the incongruities of Leonora's actual catalogue. Roughly a third of the essay consists of an unsorted list of the volumes contained in the library's heaps, including a number of classical translations and works on practical morality. In particular, the presence of Taylor's celebrated Holy Living and Dying, Locke's Of Human Understanding, ${ }^{47}$ and Steele's own The Christian Heroe heavily problematize the reading that Addison himself gives in the final lines of the essay, when he asks What Improvements would a Woman have made, who is so Susceptible of Impressions from what she reads, had she been guided to such Books as have a Tendency to enlighten the Understanding and rectify the Passions, as well as to those which are of little more use than to divert the Imagination?

Clearly, however, Leonora does demonstrate a taste for Lockean moral education through her reading (and the fact that Addison does not list any of these books as "in wood" implies that she may indeed read them). Nevertheless, this refined educational regime fails: although she compares favorably to women who "employ themselves in Diversions less Reasonable, tho' more in Fashion," Addison still identifies Leonora with the printed waste she reads. As a consequence, he separates her from polite society as a participant, reducing her instead to a

\footnotetext{
${ }^{46}$ Ibid. 6

${ }^{47}$ Addison explicitly directs his readers to Of Human Understanding in the conclusion to Spectator i. 413. See also Roy Porter, Flesh in the Age of Reason 116
} 
purely didactic literary type devoid of agency and meant solely for the observation of Addison's audience. $^{48}$

This moment, I argue, marks a critical turning point in the history of tasteful evacuation. Leonora demonstrates a taste for learning, politeness, and gentility through her reading, actions, and associations_-like the tasteful observer of Spectator 411, who "makes the Sphere of his Innocent Pleasures as wide as possible," Leonora "has turned all the Passions of her sex into a Love of books and retirement." In privacy she "converses chiefly with Men... but, it is only in their Writings," engaging in a process analogous to that described by Shaftesbury in his Soliloquy — after all, "Talking with a Friend is nothing else but thinking aloud." ${ }^{49}$ While she may lack "understanding" as Shaftesbury would conceive of it, she indisputably demonstrates the polite imagination and receptive demeanor which Addison upholds as the central characteristics of men of taste - and yet, Addison sides with Shaftesbury in this instance, barring Leonora from his circle on the basis that true taste consists of more than reading the right books and associating with the right people.

This paradoxical denial of the individual's ability to improve their taste through market means is shared across a number of Addison's essays. March 29, 1711's Spectator concerns a letter from a young man who, by obsessively perusing medical texts, has literally read himself sick with imagined illnesses. ${ }^{50}$ While Addison naturally refuses to indulge the man's hypochondriac need for "more certain Rules," neither does he deliver the expected Shaftesburian solution of privately "evacuating crudities.” Instead, Addison "answers the gentleman" by

\footnotetext{
${ }^{48}$ For a more in-depth view of how this type of didactic character functioned in the eighteenthcentury at large, John Sitter, Arguments of Augustan Wit (Cambridge University Press, 1991) pp. 19-22

${ }^{49}$ The Spectator i. 225

${ }^{50}$ For an extended reading of this letter see Roy Porter, Flesh in the Age of Reason 115-117.
} 
paraphrasing a story from La Fontaine's Fables in which a farmer accidentally ruins his harvest after being given control of the weather by Jupiter. ${ }^{51}$ In the fable, and in the Valetudinarian's dilemma, the very capacity to employ poor judgement presents a problem. Purification in such circumstances requires a quasi-miraculous transformation by means beyond the agency of those afflicted with bad taste or bad judgement_ - one can hardly detect a trace of the "tasteful selfmaking" which Gigante sees at work in Shaftesbury's writings, and which one would expect to find in Addison's. ${ }^{52}$ In a twist peculiarly reminiscent of later Tory writers' skepticism towards the market-driven man of taste ${ }^{53}$ Addison here positions the tools of taste-making as means of damnation, and treats the individual's redemption from the pit of bad taste as peculiarly uncertain.

Although incongruous with both Shaftesbury's neo-Platonism and our modern conception of Addisonian philosophy, the seemingly irresolvable tensions between circulating markets and accumulating, agency-less collectors take on a semblance of logic when considered alongside a mode of thought which had become popular in France at the end of the seventeenthcentury. Referred to in popular and medical literature as La Biblomanie, the term had been in common quasi-medical use since at least 1654, when it began to assume an alarming resonance as a disease of collecting books. ${ }^{54}$ As Jennifer Tsien writes in The Bad Taste of Others, the

\footnotetext{
${ }^{51}$ Jean De La Fontaine, Fables, trans. Norman Shapiro (Champaign: University of Illinois Press, 2007) pp. 134

52 Denise Gigante, Taste 17

53 Traditionally, this idea is also associated strongly with Pope, particularly the Epistle to Burlington. See James Noggle, The Temporality of Taste 44-46.

${ }^{54}$ Note that the English form of the term does not become a common topic for public discussion until the very late eighteenth-century, where it assumes a very different resonance connected to anxieties surrounding public libraries and the "institutional purchase" of rare books. The early eighteenth-century French concept of Biblomanie, by contrast, is connected more strongly to concerns of public taste and health than supply and demand. For more on the later Bibliomania, see James Raven, "Debating Bibliomania and the Collection of Books in the Eighteenth
} 
Biblomanié is a person, usually of a middling social class and very often a woman, in whom "the ability to read, joined with the inability to judge, and eventually the desire to write" perpetuates the debasement of a literary culture. ${ }^{55}$ For virtually all writers on La Bibliomanie (and its advanced poetry-writing form, La Metromanié) the cause of the disease is clear and readily apparent: a lack of education on the part of the average reader of books results in both misevaluating their intellectual worth and misreading their contents. ${ }^{56}$

Although there is no direct evidence that Addison had any familiarity with this concept (although such a supposition is hardly improbable, considering its popularity in France), his theory of bad taste shares with it a number of premises: Addison also views the "wretched taste" of those driving the "reigning Entertainments of the Politer Part" of his society as socially deleterious, ${ }^{57}$ associates it with accumulation, and most importantly, assigns it a clear material epidemiology arising from the intersection of poor learning and debased reading. For this reason, both Addison and the Biblomanie writers believe bad taste is fundamentally curable, at least in a society of polite individuals_-"books... proper for the improvement of the [female] sex" do exist, claims Addison, in spite of their apparent rarity. ${ }^{58}$ While he philosophes keen interest in preserving their cultural capital led to formulations based on the creation of a "closed society" of taste makers, ${ }^{59}$ Addison, to quote Roy Porter, "aimed to heal the disastrous ruptures of the 'divided society'... by means of the creation of agreeable, conformist social actors." 60

Century," Library and Information History 29, no. 3 (2013): 196-209 and Deidre Lynch, "'Wedded to Books': Bibilomania and the Romantic Essayists," Romantic Circles Praxis Series Romantic Libraries (2004).

55 Jennifer Tsien, The Bad Taste of Others 16

${ }^{56}$ Ibid. 17-22.

${ }^{57}$ See Addison's comments on recent theater performances in The Spectator i. 13 and 502.

${ }^{58}$ The Spectator i. 37

59 Jennifer Tsien, The Bad Taste of Others 11-13.

${ }^{60}$ Roy Porter, Flesh in the Age of Reason 117. 
It is no accident, then, that Addison frequently turns to medicine for his metaphors: in one Spectator he is a "doctor" prescribing "remedies" to the "seeds and principles" of bad taste, in another, he "dissects" a "Beau's Head and... a Coquet's Heart" to discover the roots of their respective distempers. ${ }^{61}$ In each case, Addison presents Mr. Spectator as an expert physician protecting the literate public from itself through the application of specially selected medicinesin this case, the tremendous volume of literary recommendations, medical advice, and distilled philosophy available in The Spectator. ${ }^{62}$ Although Addison draws a distinction between “ordinary people" and "Men of Wit" as early as Spectator $10,{ }^{63}$ later along in the paper's run it becomes unavoidably obvious that its intended audience consists at least partially of the latter group. Whether genuine or (far more likely) concocted as objects of mockery, the epistolary characters of the Valetudinarian of Spectator 27, the witless social reformer of 175, and the "sheromp" of 217 all share the essential premise of being regular readers of Addison's essays - they are all acknowledgements on Addison's part that average people suffering from the innumerable “diseases" that manifested themselves as bad taste turned to Mr. Spectator for "remedies." Casting Mr. Spectator as the leading physician to a putatively ill public taste, Addison met these demands by personally selecting the correct doses of Locke, Blackmore, and even Hobbes, ${ }^{64}$ pruning problematic passages to curate a body of public knowledge in a manner not dissimilar to Diderot's Encyclopédie.

In an ironic twist, Addison's recasting of the critic as a cultural dietician introduced a critical responsibility not merely to spectate upon society as it is, but to shape its future by

\footnotetext{
${ }^{61}$ The Spectator i. 16, 275, and 281. For more on the relationship between The Spectator, medicine, and medical metaphors, see Roy Porter, Flesh in the Age of Reason 113-129. ${ }^{62}$ Denise Gigante, Taste 52.

${ }^{63}$ See Michael Billig, Laughter and Ridicule (Thousand Oaks: SAGE, 2005) 68-69.

${ }^{64}$ The Spectator i. 281.
} 
curating and curing the reading of the common person (or, in Addison's case, the common literate, middle-class person). Introducing and ennobling this possibility allowed Addison to champion the market as a tool for self-creation—or, at least, self-affiliation—without falling into subjectivism in regard to taste, but his theorization never quite achieved the cohesion which his Tory critics craved. For Jonathan Swift in particular, the unresolved question of what happens to waste literature (and waste in general) in a tasteful society assumed a nearly maddening importance - surely, this type of critic thinks, we cannot expect Leonora to simply forget all she has read? 


\section{Swift's Quarantine}

Although he and Joseph Addison remained close friends in spite of political and personal differences, ${ }^{65}$ Jonathan Swift was profoundly skeptical of the taste-making project attempted in both The Spectator and The Tatler. Traditionally, Swift's departure from The Tatler and later opposition to the ideas espoused therein has been read as a consequence of his political break from the Whigs in 1710, and his extremely public quarrel with Richard Steele in $1712 .{ }^{66}$ Recently, however, Sophie Gee has argued that Swift's opposition to the Addison and Steele's formulation of the public sphere predates the satirist's assumption of an outspoken Tory persona,${ }^{67}$ while Abigail Williams has sketched-out a Swiftian turn toward anti-populism that predates that rhetoric's partisan associations. ${ }^{68} \mathrm{My}$ argument does not directly follow either of these lines of thinking, but it shares with both an essential premise that Swift's writings against the Addisonian ideal of taste stem from differences as philosophical as they are personal—and moreover, that Swift's earlier writing can be enlisted to develop a unique theory of taste which diverges considerably from Addison's eighteenth-century norm. Ultimately, Swift's theorization of bad literature involves a complete rejection of Shaftesburian soliloquy or "self-dissection" as an effective mode of improvement, and consequently embraces abjection and separation as solutions to the problem of print waste.

${ }^{65}$ Eugene Hammond, Jonathan Swift: Our Dean (Newark: University of Delaware Press, 2016) 106.

${ }^{66}$ Charles Knight, A Political Biography of Richard Steele (London: Pickering \& Chatto, 2014) and Henry Sams, Swift and Steele as Partisan Writers (Pennsylvania State University Press, 1967) for the historical background behind this reading.

${ }^{67}$ See Sophie Gee, “'Such Opinions Cannot Cohere': Swift's Inwardness," Republics of Letters 4, no. 1 (October 2014).

${ }^{68}$ Abigail Williams, Poetry and the Creation of a Whig Literary Culture 1681-1714 (Oxford University Press, 2005) pp. 22-52. 
The profound differences in the Addisonian and Swiftian conceptions of print waste arise from mutually irreconcilable theories of literary production. Addison envisions the mind in a manner not terribly dissimilar to Milton: his chosen metaphor is a box of medals, with each individual experience or idea selected from inside or out, properly evaluated, carefully polished by extensive reflection, and perhaps, in time, shared with the world. ${ }^{69}$ In A Tale of a Tub, Swift instead envisions the acts of philosophical thought and artistic creation as occurring over a chamber pot, where Understanding "must be troubled and overspread by vapours, ascending from the lower faculty to render it fruitful.,"70 Where Addison exalts ancient coins as "poetical cash," a method for organizing and generating new ideas, ${ }^{71}$ Swift intends his metaphor as an extended joke with the reader as its butt. The process of writing a "modern" book, suggests Swift's scribbling narrator, consists of consuming "the latest refinements in knowledge, running parallel to those of diet in our nation... consisting in soups and olios, fricasses and ragouts" and excreting them as products that, although they "differ both in kind and degree," are inevitably degraded compared to the originals. ${ }^{72}$ Repulsively, this is not the end: Swift's digestions retain their vigor afterwards, resulting in endless wasted labor as the "constant supply" of food creates

\footnotetext{
${ }^{69}$ Joseph Addison, "A Dialogue upon the Usefuleness of Ancient Medals," in The Works of Joseph Addison, vol. 3, 3 vols. (New York: Harper and Brothers, 1864), 273-80 pp. 274. See also Sean Silver, The Mind Is a Collection (New Haven: Yale University Press, 2015) pp. 129140

${ }^{70}$ Jonathan Swift, A Tale of a Tub, ed. Angus Ross and David Woolley (Oxford University Press, 2008) pp. 78. This is, of course, one of Swift's most enduring metaphors and has been written about extensively. In particular, the readings advanced in Brad Pasanek, Metaphors of Mind (Baltimore: Johns Hopkins University Press, 2015) pp. 216-218, and Michael McKeon, The Secret History of Domesticity (Baltimore: Johns Hopkins University Press, 2006) pp. 292-293 have been influential in my interpretation.

${ }^{71}$ See Sean Silver, The Mind is a Metaphor 129-133

72 Tub 69-80. Interestingly, Hugh Ormsby-Lennon suggests that this moment draws its satiric energy from an already-existing language comparing ephemeral printed materials to food, home remedies ("kitchen-physik"), and from there, legitimate medicine. See Hugh Ormsby-Lennon, Hey Presto! (Newark: University of Delaware Press, 2011) 30-31.
} 
a need for "large indexes, and little compendiums" of quotations, forever rendered useless by the abject nature of their subjects. ${ }^{73}$ In Swift's metaphor, the consideration of these dregs, and their consumption, is left to the "true criticks" - the type of both the Tale's audience and its writerwho are compelled to "drag out the lurking errors" of texts, "multiplying them like Hydra's heads; and raking them together like Augeas's dung." 74

It is this final step-in which Swift, like a Grubean alchemist, "proceeds by reincrudation" to transform bad works into worse ones - that sets A Tale of a Tub's print waste apart from that of Areopagitica or the Spectator. As much as Milton's books threaten to "spring up armed men," or Addison's romances to lull their readers into "lethargy," only the Grub Street's printed "children of the brain" contain such life as to survive and reproduce after repeated cycles of birth and consumption. ${ }^{75}$ Even more than Addison, Swift shares the Philosophes' fear of the reader of bad literature taking up the quill as a metromané, or a compulsive bad writer. ${ }^{76}$ Put another way, where printed waste disrupts Addison's economy of cultural interchange, Swift positions it as creating economies of its own, generating endlessly to malign effect.

This early acknowledgement of the self-replicating power of bad ideas may begin to account for Swift's later pessimism towards both the Shaftsburian soliloquy and The Spectator's "remedies." Denise Gigante notes that Swift's Letter to a Young Poet, in which he effectively suggests "cordoning off a quarter of the town" so that hacks may "dispose of their mental rudeness," inflates and parodies Shaftsbury's Soliloquy even as it seems to endorse the

73 Tub 71. See also Ann Blair, Too Much to Know (New Haven: Yale University Press, 2010) pp. 230-264 for an extended discussion of indexes and index-anxiety in the eighteenth-century.

${ }^{74} \mathrm{Tub} 45$.

${ }^{75} \mathrm{Tub} 33$.

${ }^{76}$ Jennifer Tsien, The Bad Taste of Others 17-18 
underlying pattern of base, malodorous gunk pulling down the faculties of the ascendant thinker. ${ }^{77}$ Of course, Swift quickly clarifies his position on the "society of the reformation of manners" when he defends the creation of a publicly-funded "apartment for the Muses" as both a residency (and, Swift heavily implies, a brothel) for good writers, as well as "safe repository for [tasteful society's] best productions"78 — an expression, if nothing else, of the pointless expense and questionable sense of promoting the public taste through private expression.

Swift treats Addison's attempt to medicalize the problem of bad taste with equal derision. Hugh Ormsby-Lennon has already written extensively on the ways in which A Tale of a Tub apes and mocks eighteenth-century quack-doctor and stage-itinerant cultures, but it is worth noting how many of its invocations of chicanery double as digs at The Spectator and its readers. Like Mr. Spectator, Swift's Hack promises "a wonderful revolution in [the] notions and opinions" of his readers, and emphasizes his treatise's suitability to the tastes of diverse individuals — by which Swift means that he expects his audience to be amused and outraged, not edified ${ }^{79}$ Also like Mr. Spectator, the Hack eagerly begs for the "assent” of his "judicious reader" at every turn, drawing them into dialogue-but he does so in the manner of a profiteering mountebank, knowingly peddling snake-oil under the pretenses of the public good. ${ }^{80}$ And where Addison jokingly affects a surgical air in his "dissections of a Beau's Head," finding therein "laces" and "mirrors," the Hack discovers "faults" upon "seeing a woman flayed" or a "the carcass of a

\footnotetext{
${ }^{77}$ Gigante, Taste 52-54.

${ }^{78}$ Jonathan Swift, The Prose Works, ed. Herbert Davis, vol. 7, 14 vols. (Oxford: Basil Blackwell, 1939) pp. 144. It is not unlikely that this passage may have influenced Bernard Mandeville's later Defense of Public Stews - see Claude Rawson, Swift and Others (Cambridge University Press, 2015) pp. 51-52 for a brief account of Mandeville's familiarity with Swift.

${ }^{79}$ Tub 89, compare to Addison's claims in The Spectator i. 10. See Hugh Ormsby-Lennon, Hey Presto! 24-26 on this passage, the advertisement for A Tale of a Tub, and Swift's rendition of "quacksalver's patter" in general.

${ }^{80}$ Hugh Ormsby-Lennon, Hey Presto! 65, 103-104.
} 
beau" laid open — but Swift never acknowledges the nature of these "imperfections," because the target of his satire is plainly the voyeur-surgeon himself. ${ }^{81}$ More so here than in the "Letter to a Young Poet," Swift reveals the quest to commercially "cure" the public taste by exposing the bad and prescribing the good as not simply pointless or deluded, but actively vulgar and transparently pecuniary in interest.

We need not read these parallels between the Hack and Mr. Spectator as personal animosity. Instead, I argue that they reflect a wider Swiftian anxiety surrounding the differentiation of different types of waste, as described in Sophie Gee's work. In her examination of Swift's writing in general and "Directions to Servants" in particular, Gee notes an inescapable tendency to conflate the sacred and profane: in the servants' hands, the chamber pot becomes "a vessel" containing communion wafers or, nauseatingly, "canapés." 82 The uncomfortable implication here, as Gee sees it, is that the magic of the page draws those categories together, and makes it easy to mistake one for the other even for those of an otherwise sensitive faculty of taste. ${ }^{83}$ This, I believe, is why Swift so often configures literary waste as human waste, rotting carcasses, and other points from which "bad air" emanates_-because while they might smell different to the nose capable of recognizing their scent, toxic vapors cannot be distinguished from uncontaminated air without partaking of their miasma. ${ }^{84}$ In the same way, the persistence of mimesis as a mode of thought meant that the difference between a learned author's parody and a

\footnotetext{
${ }^{81} \mathrm{Tub} 84$.

${ }^{82}$ Sophie Gee, Making Waste 14-16.

${ }^{83}$ Ibid. 14-16, 92-112

${ }^{84}$ As Paul Hunter notes, "the many accounts of eighteenth-century sense experience... all bear a consistent record of personal invasion," particularly where the smells of disease and rot were concerned. See Paul Hunter, Before Novels (Cambridge University Press, 2015) pp. 118-130, particularly the discussion of Defoe's Journal of a Plague Year on 123-124.
} 
genuine hack's excretions was not always obvious - a fact borne out in the reception history of both A Tale of a Tub and Gulliver's Travels as genuine examples of their respective genres. ${ }^{85}$

Clearly, Swift sees little hope for redemption of the public taste- printed waste is too great in mass, too generative, and too difficult to identify, while its purported opponents hardly seem to take it seriously. With regards to the individual, however, Swift seems harder to read. On the one hand, Gigante notes occasional appeals to those of "good noses" which imply the existence of a tasteful class against which the debased tastes of the general public contrast ${ }^{86}$ but, as Claude Rawson points out, Swift tends to see the "potential for freewheeling mental excess and moral depravity" as a universal human trait, in which satirists themselves were complicit. ${ }^{87}$ If Shaftesbury's purgation of rudeness remains at all possible in Swift's world, even on a personal level, it must involve a more total separation from printed and societal waste than that achievable through the mechanism of satire, the "writers" of which wear "very foul clothes" and "leave more filth and nastiness than they sweep away." 88

One of the central problems that any such theory of evacuation would have to face, in Swift's conception, lies in dealing with the persistent traces of printed waste within the memory of the individual. This can be seen most clearly in Gulliver's descriptions of the Struldbrugs, men and women who suffer from Tithonus-esque eternal life without youth. ${ }^{89}$ Upon first hearing of the Struldbrugs, Gulliver reacts by imagining himself an immortal Mr. Spectator:

${ }^{85}$ Claude Rawson, Swift's Angers (Cambridge University Press, 2014) pp. 142.

${ }^{86}$ Denise Gigante, Taste 53.

${ }^{87}$ Claude Rawson, Swift's Angers 8-9. See also Claude Rawson, Swift and Others 58 for a discussion of Swift's pessimism in general.

${ }^{88}$ The Prose Works, Vol. 7 pp. 142. See also Hugh Ormsby-Lennon, Hey Presto! 101-102 on the similarity between A Tale of $a \mathrm{Tu} b$ and self-parodying advertisements for quacks.

${ }^{89}$ Jonathan Swift, Gulliver's Travels, ed. Albert Rivero (New York: Norton, 2002) pp. 175-182 
...I would from my earliest Youth apply myself to the study of Arts and Sciences, by which I would arrive in time to excel all others in learning. Lastly, I would carefully record every action and Event of Consequence that happened in the Publick, impartially draw the Characters of the several Successions of Princes, and great Ministers of State, with my own Observations on every Point. I would exactly set down the several changes in Customs, Language, Fashions of Dress, Dyet and Diversions. By which all Acquirements, I should be a Living Treasury of Knowledge and Wisdom, and certainly become an Oracle of the Nation..$^{90}$

One might here catch a whiff of the same wistful longing for a polite world that Gigante notices in the "Letter to a Young Poet". Just as in the "Letter," however, Swift subverts this dream by introducing Gulliver to a satiric reality in which the Struldbrugs live in constant misery due to their inability to remember events past the age of eighty. This tragic dementia, as well as the horrid prospect of an eternal life, renders them yoked to "prevailing passions" of "Envy and impotent Desires"-in effect reducing them to creatures of the very appetites which Addison sought to restrain. The prospect of eternal life, far from giving the Struldbrugs infinite opportunities to evacuate their flaws, instead alienates them from polite society entirely.

This strikingly unsympathetic description of the Struldbrugs is most often read as an expression of Swift's fear of senility, similar to the lines on "the Dean beginning to break" in Verses on the Death of Dr. Swift. ${ }^{91}$ However, Swift's mention of a second, less miserable type of Struldbrug, who "turn to Dotage, and entirely lose their Memories" and therefore "want many bad Qualities which abound in Others," suggests an accumulatory conception of abjection-that

\footnotetext{
${ }^{90}$ Ibid. 177

${ }^{91}$ See Claude Rawson, Swift's Angers 121-123.
} 
the Struldbrugs vices arise not as an innate product of growing old, but as a consequence of accumulating so great a quantity of material dregs as to prevent entry into the Addisonian society of good taste. ${ }^{92}$ Swift's irony, of course, lies in the fact that their unwilling method of evacuation - the forgetfulness of senility — prohibits the Struldbrugs who suffer from it from improving the taste of others through their own judgement, now purified. Swift thus renders Gulliver's initial fantasy of an undying man of taste absurd on two fronts, problematizing both the concept that individual evacuation of the traces of a degraded or debased society is possible, and the idea that a return to the state of nature is at all preferable. ${ }^{93}$

Swift's descriptions of the Houyhnhnms both confirms the centrality of external causes to degrading both the public and individual taste, and suggests a solution. Like the people of Laputa, the Houyhnhnms are avowed rationalists-however, while the Laputans' professed wisdom conceals useless pedantry, ${ }^{94}$ Gulliver views the Houyhnhnms as members of an "orderly... rational, acute and judicious" not unlike that sought after by Addison. ${ }^{95}$ This social harmony is made possible by both the Houhynhms total physical and linguistic separation from the Yahoos, their isolation from the rest of the world, and their complete absence of a print

\footnotetext{
92 A similar idea is expressed by Rousseau, who in Sciences et Artes "imagines future generations crying out to their God, 'deliver us from the enlightenment, and the fatal arts of our fathers, and give us back ignorance, innocence, and poverty" (as quoted and translated in Jennifer Tsien, The Bad Taste of Others 35). Older discourses of forgetting and idealizing primitive institutions were available as well—see Tony $\mathrm{C}$. Brown, The Primitive, The Aesthetic, and the Savage 26-44 on contemporary sources.

93 Swift may have had in mind Steele's assertion that age improves "all the rational and worthy pleasures of our Being" in The Spectator i. 153.

${ }^{94}$ See Gregory Lynall, Swift and Science (New York: Palgrave, 2012) pp. 89-119 on Laputa as a parody of the Royal Society of Physicians. As Lynall notes, Swift's satire tends to mock the Laputans' (and the "Laputans" of the Royal Society's) obsession with trivia, self-righteousness, and lack of common sense, rather than faith in evidence-based reasoning that they share with the Houyhnhnms.

95 Gulliver's Travels 191. Compare to Addison's description of the "constant and assiduous" culture of "well-regulated families" of readers in Spectator i. 10.
} 
culture $^{96}$ — as a result, there is no way for print waste to enter Houhynhmland, nor for Addison's

"Follies" to artificially preserve themselves in the culture and reproduce. The Yahoos are

particularly notable, as their presence asserts again the link between waste and the degradation of taste - the Yahoos represent "waste people" in every sense, being both obsessed with their own feces and, as underutilized and constantly procreating bodies, wasted labor. Because the Houyhnhnms have no verbal intercourse with the Yahoos, however, they never suffer from the putrification of taste or judgement that defines Addison's waste readers.

This logic of excision does not confine itself to the fantastical islands of Gulliver's Travels, however. As Claude Rawson notes in God, Gulliver, and Genocide, Swift frequently flirts with an ambiguous rhetoric of removing or exterminating those who threaten the "public good." ${ }^{97}$ Swift's discussion of the Houyhnhnms' voluntary alterity from the Yahoos gleefully engages this suggestion: while we are surely meant to feel disgust at the mention of utilizing Yahoo hides as sails, it is "presented as a matter of what men do to beasts," 98 or indeed, as a "useful" (if disgusting and immoral) commodification of "raw materials" not dissimilar to Swift's proposal in an earlier pamphlet that the "unsupportable" segments of the Irish population be sold as slaves. ${ }^{99}$ It is in this way fundamentally different from the horror engendered by $A$ Modest Proposal, where, as Rawson astutely points out, the horror originates less from the abjection of the Irish poor than from the "assimilation" of the Anglo-Irish colonizing class into

\footnotetext{
${ }^{96}$ See Terry Castle, "Why the Houyhnhnms Don't Write: Swift, Satire, and the Fear of Text," Essays in Literature 7, no. 1 (1980): 31-44 and Charlotte Sussman, Consuming Anxieties (Stanford University Press, 2000) pp. 61-63 on Swift's suggestion of (disastrous) cultural contact between Houhynhnmland and Europe.

${ }^{97}$ See Claude Rawson, God, Gulliver, and Genocide (Oxford University Press, 2001) pp. 183254 for a complete analysis of this rhetoric

98 Ibid. 84-85

${ }^{99}$ See Charlotte Sussman, Consuming Anxieties 63-74.
} 
"their own most despised subgroup" "100_ in other words, the consumption of waste, and its implied contamination throughout that social stratum. The deficiency in the speaker of $A$ Modest Proposal's character does not lie solely in his coldness or cruelty, but in his flawed assumption that the Irish can ever be "sound and useful members of the common-wealth," even as food.

Of course, as the immense quantity of literature pointing to the satirical connotations of Swift's characterizations of Houhynhmland points to, ${ }^{101}$ Swift follows Thomas More in setting up a thoroughly imaginary Utopia, not to be attempted. ${ }^{102}$ Even Gulliver, regarded as a lunatic by the end of his travels for his misanthropy and obsessive, quasi-sexual fascination with horses, fails to wholly separate himself from the "Yahoo" society, instead aiming to "reconcile" himself to "the Yahoos of [his] own Family, as [he] finds them docible Animals."103 Nor does Swift ever, like the more vindictive philosophes, fantasize about public book-burnings. ${ }^{104}$ Charitably, we may view Swift's recurrent image of excising bad taste from society in service to a tasteful elect as a deliberate satire of the improvement of the public taste, taken to its absurd and morally deficit conclusion-less generously, it is a pining and knowingly impossible dream of a society where those who grate on his nerves have been eradicated.

Regardless of its seriousness, Swift's dream of an England radically separate from the bad taste of its inhabitants lives on in the poetry of Alexander Pope, whose pastorals present a

${ }^{100}$ Claude Rawson, Swift's Angers 16

${ }^{101}$ See James Clifford, "Gulliver's Fourth Voyage: Hard and Soft Schools of Interpretation," in Quick Springs of Sense, ed. Larry Champion (Athens: University of Georgia Press, 2011) pp. 3351.

102 Although on the other hand, see Swift's Proposal for giving Badges to Beggars, where he advocates that "foreign beggars... must be driven or whipped out of town" without a shred of irony, essentially putting a similar system of quarantine into practice for a demographic widelyseen as tinged or tainted by waste. See Claude Rawson, God, Gulliver, and Genocide 183.

103 Gulliver's Travels 249-250.

${ }^{104}$ See Jennifer Tsien, The Bad Taste of Others 29 
kinder and gentler vision of an England where all bad taste has been evacuated, and all waste neatly dealt with. Swift's sense of print waste as a truly insurmountable obstacle to the worldly realization of a polite society remains with Pope, however, as evinced in the 1743 Dunciad's grandly Swiftian conclusion, where heaps of false wit and "mountains of casuistries" systematically murder all traces of good taste in London. ${ }^{105}$ In this darkest possible future, the proto-Malthusian implications of Swift's evacuative ideology are nightmarishly-inverted and taken to their most extreme conclusion: endlessly generative bad taste, far outweighing the limited powers of polite individuals, refuses all containment and awakens a new era of dullness.

105 Alexander Pope, Poems of Alexander Pope, ed. James Sutherland, vol. 5, 11 vols. (London: Methuen, 1961) 4.626-656 
Pope's Paradise

Up until now, this essay has functioned largely as an attempt to contrast Joseph Addison and Jonathan Swift as early theorists of print waste in conversation by virtue of shared premises, rather than any profound similarity in their conclusions. It is tempting to position Alexander Pope's nascent theory of waste as a compromise between the other two, but such a claim would be misleading, as his relationship to the public taste was more complicated than either Addison's or Swift's. As late as the 1744 revision to The Epistle of Burlington, Alexander Pope remained an ardent critic of "the abuse of the word Taste" by Walpole's social circle, writing ceaselessly to recover the philosophical, sensual, and poetic world of taste from the commercial and, by the 1730 's, Whig-coded usage of the word. ${ }^{106}$ I argue that this censorious critical posture which privileges the individual capable of distinguishing "false taste" and art from higher truth lies at the core of Pope's curiously Miltonic conception of printed waste as a testing ground for distinguishing good readers from bad. ${ }^{107}$ In articulating a distinct theory of waste based around this concept, Pope draws on elements in both Addison and Swift's writings but rejects their conclusions, returning instead to a Miltonic conception of print waste as a useful tool to ascertain the worth of readers.

In his writing dealing explicitly with printed waste, Pope tends to strongly cohere with Swift in aligning the public taste with degraded Mandevillian appetites. Nowhere is this clearer

\footnotetext{
106 See James Noggle, The Temporality of Taste 40-63

107 This is, of course, exactly what Milton argues in Areopagitica: that bad books "promiscuously read" have the potential to "purify us" by testing "virtue... which is but a youngling in the contemplation of evil, and knows not the utmost that vice promises her followers" (Complete Prose 728). Milton is, of course, much more concerned with books of negative moral value - to apply this logic to aesthetics is Pope's innovation.
} 
than in The Dunciad, in which the preponderance of printed trash littering London brings on a literal apocalypse of taste. ${ }^{108}$ There, London's “Grubstreet Race” produce occasional genres, "New Years Odes" and the like, that, while lapped up by the public, lack the immortality that serves as an atemporal judge of literary quality and poetic accordance with nature. ${ }^{109}$ In order to serve this "weekly muse" of public appetite and fill their own bellies, the uneducated and untalented hacks of the Dunciad collect and consume a disorganized smorgasbord of excessive texts ranging from Ogilby’s translations ("'printed," fawns Scriblerus, "on such large paper!") to the works of the Scriptural commentator Nicholas de Lyra-which they then, in true Swiftian fashion, literally piss away into the chamber pot of history. ${ }^{110}$ Pope's charge recalls that of $A$ Tale of a Tub's narrator, comparing contemporary literature to “Ollio’s, Friccassés, and Ragousts" - that the overwhelming public desire to consume predigested occasional literature results in the devaluation and impossibility of higher forms. ${ }^{111}$ Like Swift but unlike Addison, Pope identifies this failure of public taste and consequent fading of the light of English culture with the motives behind the production of print waste: as Scriblerus notes in a moment of uncharacteristic clarity, Pope "imputes all" that he satirizes "not so much to Malice or Servility, as to Dulness; and not so much to Dulness, as to Necessity." ${ }^{112}$ Engaging in the same association

\footnotetext{
${ }^{108}$ For Swift's influence on The Dunciad, see Dustin Griffin, Swift and Pope 107-128, Claude Rawson, Swift and Others 91-95, and David Vander Meulen, ed., Pope's Dunciad of 1728 (Charlottesville: University Press of Virginia, 1991) pp. 3-16

${ }^{109}$ Poems vol. 5 1.37-42. For longevity as a judge of literary quality, see the "Essay on Criticism" in Poems vol. 1 pp. 246-251, especially pp. 249 n. 88f. However, note also that the goddess Dullness is explicitly immortal (Poems vol. 5 1.16)—Pope, uncomfortable with the idea of preserving his Dunces, adds order to longevity as a criterion for poetic greatness.

${ }^{110}$ Poems vol. 5 1.120-142, 72 n. 120, 121, 74 n. 133, \& 153-183. For Pope's varying uses and critiques of the professional hack, see Pat Rogers, Grub Street: Studies in a Subculture (London: Methuen, 1972) pp. 186-195.

${ }^{111}$ Henry Power, Epic into Novel (Oxford University Press, 2015) pp. 3-4

112 Poems vol. 5 1.58. See also Pat Rogers, Grub Street 188-190.
} 
between Addisonian market-taste and appetite that marks Swift's satire, ${ }^{113}$ Pope insists on the futility of improving taste as long as poor poets write to eat.

As Abigail Williams notes, however, Pope contradicts this movement away from a market evaluation of taste when he implies that the writers of Grub Street "hunger... and thirst, for scribling sake," or in other words, that they remain poor on account of the poverty of their verse. ${ }^{114}$ In this moment, at least, Pope sides with the judgement of the purchasing public, and seems to endorse the validity of their valuation. While it hardly seems surprising that Pope should valorize certain public judgements in light of the popularity and controversy of his Iliad, I argue that there is more than hypocrisy at work in Pope's incomplete accession to Swiftian tasteskepticism. ${ }^{115}$ As David Morris observes, Pope embraced occasional poetry throughout his career, and his early writing is full of market metaphors and references to poets as merchants. ${ }^{116}$ In particular, Morris cites the 1713 Windsor-Forest as an example of Pope's early enthusiasm for the "commercial spirit," noting its undifferentiating embrace of the language of prosperity contrasting with the poet's later "questioning" and satirizing of financial institutions in the wake of the South Sea Bubble. ${ }^{117}$

I do not aim to dispute this view, but instead to suggest that Pope's revisions to both Windsor-Forest and the Pastorals introduce an aesthetic dimension to Pope's occasional, unexpected glorification of "miraculous transformations" and regular Addisonian economies of

113 See Denise Gigante, Taste 52-54 and James Noggle, The Temporality of Taste 40-63.

${ }^{114}$ Williams, Poetry and the Creation of a Whig Literary Culture 54. 49-55. DV 1.48. See also Tibbald's "supperlessness" in the Dunciad (Poems v.5 1.109).

${ }^{115}$ Henry Power, Epic into Novel 94-99

${ }^{116}$ David Morris, Pope: The Genius of Sense (Cambridge: Harvard University Press, 1984) pp. 7-9. See also pp. 15-47 for the importance of occasional poetry in both Pope's oeuvre and the eighteenth-century in general.

${ }^{117}$ Ibid. 179-213. See also Sophie Gee, Making Waste 83-87 and Dustin Griffin, Swift and Pope 73-74 on the impact of the South Sea Bubble on Pope. 
perfect repatriation. ${ }^{118}$ In particular, Pope's 1732 Windsor Forest includes the following lines comparing his subject to Eden in unambiguously acquisitive terms:

And 'midst the desart fruitful fields arise,

That crown'd with tufted trees and springing corn,

Like verdant isles the sable waste adorn.

Let India boast her plants, nor envy we

The weeping amber or the balmy tree,

While by our oaks the precious loads are born

And realms commanded which those trees adorn. ${ }^{119}$

As with The Dunciad, Pope echoes Paradise Lost: Audra and Williams gloss the "weeping amber" and "balmy tree" as potential recollections of Eden's "Groves," 120 while the 1732 version's deliberate addition of "fruitful fields" in the "sable waste" invokes the Miltonic conception of wasteland as largely unproblematized verdancy ennobled by the labor of cultivation. So extensive is this natural bounty that its utilization takes on a moral dimension later in the poem, when Pope describes how the "kind Seasons swell the teeming Grain" of England's fields "in vain" under the wasteful Norman regime, and directly links this unaccounted-for excess to the starvation of the peasantry and overturning of the natural order. ${ }^{121}$ If there is any taste theory at work in this passage, it is that of the unproblematized consumption of Areopagitica - the chief concern lies in the public access to bread, not what to do after that bread is digested.

\footnotetext{
118 Ibid.

${ }^{119}$ Poems vol. 1 150-151. See Poems Vol 1, p.150 n.25 for Pope's changes between the two editions.

120 Poems vol. 1, p.151 n 30

121 Poems vol. 1152.
} 
These resonances, although strikingly different from those present in The Dunciad, seem on their surface consistent with Pope's politics - as much as he views surplus skeptically when it comes to print, Pope invariably engages in fairly conventional eighteenth-century exaltation of material production as natural and ideal. ${ }^{122}$ The same cannot be said for Pope's invocation of the colonial "realms commanded" by British naval power, which inexorably draw his verses into the web of commerce and public taste. As Pope himself acknowledges in the Epistle to Bathurst, "what Nature want extends to luxury, extends to lust,"123 and he would hardly be alone in realizing that the public appetite for foreign luxuries (particularly sugar) drove the colonial and international trade to which Windsor-Forest's ships allude. ${ }^{124}$ The exact function of these vessels remains ambiguous, however, and just as in Addison's Exchange it is possible to imagine economies of colonial waste forming in the margins of enlightened exchange- are these slave ships, and if so, is the English appetite for sugar ultimately an appetite for human suffering? ${ }^{125}$ Pope leaves this question unanswered, and perhaps unconceived. ${ }^{126}$ Instead, the hazily mythic near-past setting, enlistment of the oaks as active participants, and persistent conceit of monarchial omnipotence together lead to a total elision of group agency with regards to Windsor

${ }^{122}$ For an extended analysis of Pope's relationship to labor and production, Leopold Damrosch, The Imaginative World of Alexander Pope (Los Angeles: University of California Press, 1987) pp. 55-139.

${ }^{123}$ Poems vol. 3.2 26. For an extended reading of these lines, see Leopold Damrosch, The Imaginative World of Alexander Pope 72-73.

${ }^{124}$ See Simon Gikandi, Slavery and the Culture of Taste 109-125

${ }^{125}$ For more on Windsor Forest and slavery, see Howard Erskine-Hill, "Pope and Slavery," in Alexander Pope: World and Word (London: British Academy, 1997) pp. 27-55 and John Richardson, "Alexander Pope's 'Windsor Forest': Its Context and Attitudes towards Slavery," Eighteenth-Century Studies 35, no. 1 (Fall 2001): 1-17.

${ }^{126}$ Alternatively, Scott Cleary, "Slouching toward Augusta: Alexander Pope's 1736 'Windsor Forest," Studies in English Literature 50, no. 3 (Summer 2010): 645-63 pp. 649-651 for a possible reading of these lines as reflecting Pope's anxiety surrounding England's colonies overseas. 
Forest's economies_-England's wealth abounds because "a STUART reigns," and the indirect causes of its commerce are neatly avoided. ${ }^{127}$

There is a voice other than Milton's at work in these lines, where trees are converted freely from ships and back in terms not dissimilar to the Epistle to Burlington's "future navies." In erasing any hint of waste or labor, and avoiding the violently precarious circumstances of England's "rule" in India, Pope recalls the miraculous fungibility of Addison's stock exchange, where "the fruits of Portugal are corrected by the Products of Barbadoes" and the two come together as means of exchange. ${ }^{128}$ Swift's anxieties over the power of print to mimic financial conversion $^{129}$ are entirely absent in all versions of Windsor Forest, where the local deforestation and colonial reforestation of England's imperial shores gives way to "Rich Industry... smiling on the Plains." ${ }^{\prime 130}$ Despite their shared skepticism of credit and stock-based exchange, in this instance Pope glorifies the Edenic transformation that Swift rejects totally, and upholds a seemingly Whiggish and distinctly Addisonian vision of certain tastes driving nationally beneficial economies of endless and unthreatening surplus. The result is an anti-Dunciad set in material terms, where Addison's modern imperative to "repatriate waste" is obviated by an overtly miraculous, literal transformation of one good for another.

For Susan Staves, an answer to Pope's puzzlingly commercial turns lies in his and Addison's shared affinity for public improvement: in attempting to refine the taste of the polite ladies and gentlemen of his readership, Pope engaged in "a kind of bourgeois and nationalist scheme for improvement" closely aligned with that which Addison attempted in The

127 Poems vol. 1152

128 The Spectator i. 69. See Sophie Gee, Making Waste 137-143.

${ }^{129}$ Ibid. 91-111.

130 Poems vol. 1151. 
Spectator. ${ }^{131}$ As with Addison, Pope never elaborated fully on the ideological basis of this attempt, and its goals fluctuated in scope between the early Windsor-Forest, where the worst inclinations of human beings are kept in check by the ordered institutions of a poetic society, ${ }^{132}$ to the near-oblivion of The Dunciad. ${ }^{133}$ Ultimately, however, the mechanism for this scheme was the pleasure of reading's Pope's verse — as he wrote to Swift in 1725, Pope was happy to "divert... the world too if it pleases," rather than vex it via Swiftian satire. ${ }^{134}$ Like Addison, Pope rejects the Mandevillian conception of appetite, instead upholding a view of enlightened taste which allows individuals to refine their temperaments through monetary acts, although he is also careful to distance himself from the Walpole circle's crass commercialism. ${ }^{135}$

As Dustin Griffin notes, however, Pope's response to Swift's profoundly cynical claim to "hate and detest that animal called man" is not total rejection. On the contrary, Pope asserts (with no slight irony) full agreement with what he diplomatically refers to as Swift's "love of individuals," although he quickly clarifies that he views this love in a manner similar to Shaftesbury, as a "widening circle" that comes to encompass the public. ${ }^{136}$ This conception of

${ }^{131}$ Susan Staves, "Pope's Refinement," The Eighteenth Century 29, no. 2 (Spring 1988): 145-63 pp. 153

${ }^{132}$ Poems vol.1 139. Note that this is in part political performance, and an indictment of the early Whig's poeticization of "martial virtue." See Abigail Williams, Poetry and the Creation of a Whig Literary Culture 1681-1714 pp. 228.

${ }^{133}$ As Claude Rawson has written, however, Pope's imagery and narrative voice in the Dunciad Variorum betrays an "imagination... not whole-heartedly committed" to the cynical apocalypse of the final version. See Rawson, Swift and Others 92-93.

${ }^{134}$ Howard Erskine-Hill, ed., Selected Letters of Alexander Pope (Oxford University Press, 2000) pp. 51. For an extended reading of this letter, see Dustin Griffin, Pope and Swift 75-82. ${ }^{135}$ See James Noggle, The Temporality of Taste 43-45 for a discussion of Pope's reservations in this matter.

${ }^{136}$ Dustin Griffin, Pope and Swift 75-82. Pope also expresses a truncated version of this view in the Essay on Man 3.317-318:

Thus God and Nature linked the gen'ral frame, And Bade self-love and social be the same 
affection, while reminiscent of the polite circle of The Spectator's readership, differs from it in function. Mr. Spectator treats his readers as participants in a project of tasteful improvement, validating their desire for education and suggesting that even those of unrefined understanding can hope for improvement through continued participation in his scheme. Pope, on the other hand, yearns for "a kingdom of the Just" free from both Earthly distempers and, more disconcertingly, the scurrilous "creatures of this world" whom Swift so loves to vex ${ }^{137}$ — his vision of paradise, whether Earthly or heavenly, is defined by the evacuation, rather than integration or redemption, of bad taste and its associated print waste. Taste and pleasure, Pope suggests, can be had, and the Mandevillian appetites underlying them glorified-but only once the unworthy, the immoral, and the Duncical have been evacuated from the polite economy. ${ }^{138}$ Pope never hides his distaste for his poetical and political enemies, but the justification for this scorn is attributable to more than mere personal distaste. While Addison makes it easy to imagine the kind of universal affection and sensibility that makes the Royal Exchange's paradise possible, Pope's political focus obfuscates what circumstances (beyond an impossible Stuart succession) drive the economies of Windsor-Forest. Why do its references to the endlessly generative wasteland remain untainted by the noxious specter of print waste?

A seemingly unrelated collection of verses from Winter - another early pastoral that Pope revised throughout his career-in which a shepherd invokes his deity presents one possibility:

To thee, bright Goddess, oft a Lamb shall bleed,

${ }^{137}$ Letters 51-52.

${ }^{138}$ Other works have defined the exact nature of these qualities - what makes someone a Dunce, in other words - in greater detail and completeness. See Pat Rogers, Grub Street: Studies in a Subculture 175-217 
If teeming Ewes increase my fleecy Breed.

While Plants their Shade, or Flow'rs their Odours give,

Thy Name, thy Honour, and thy Praise shall live! ${ }^{139}$

Pope saw the "air of Piety" as essential to the Elysian chronotope of Pastoral poetry. ${ }^{140}$

Nevertheless, he reconfigures the rite that should, in theory, form the sacred core of Hellenistic religion into a modern economic exchange dependent on reciprocation—Lycidas offers his lambs only if their numbers increase, and his continued praise is contingent upon nature's continued beauty. Of course, because the pastorals occur in a "Golden Age" outside of real time or history, ${ }^{141}$ these promises are devoid of real tension — the reader of pastorals assumes, by convention if not Pope's own discourses, that Lycidas's sheep will breed plentifully and the landscape rejuvenate readily in the Spring. The result is what Georges Bataille would refer to as a "restrictive economy," where the excessive fecundity of Lycidas's "teeming Ewes" is kept entirely in check by the waste-free disposal system of religious sacrifice. ${ }^{142}$

Although remarkable in its conditionality, this system of sacrifice closely follows the chief ideological precept set down in the Discourse on Pastoral Poetry-the system regulates itself, and in this way, the "miseries" that make up rural labor in the real world are "concealed." ${ }^{143}$ As Claude Rawson notes, however, this directive does not demand to the removal of poetic miseries, like those experienced by Winter's suicidal shepherd, but instead serves to "methodize" the modern pastoral, and bring it into continuity with Virgillian models of

\footnotetext{
139 Poems vol. 1 94-95.

${ }^{140}$ Poems vol. 124.

141 Ibid.

142 Bataille defines the "restrictive economy" as one either lacking or lacking concern for surplus, as opposed to the "economy considered in general," in which excess material "must necessarily be lost without profit" (The Accursed Share vol. 1, 19-26)

143 Poems vol. 124.
} 
poetry and critique. ${ }^{144}$ Likewise, Pope's portrayal of truly restrictive economies in which waste is either avoided entirely or evacuated completely serves to separate, rather than bring together in the positive Addisonian or negative Swiftian senses, the material world from the poetic. The transformative power here, far from the inert dregs of Swift's Tale of a Tub, suggests the possibility of a real and substantial classical inheritance of the same type represented in Pope's lifetime attempt to fashion himself as a modern-day Virgil. ${ }^{145}$ The combination of radical fungibility between things of different qualities and the possibility of atemporal poetic evacuation lets Pope make exchanges between time periods, as when he apostrophizes in classical terms the "God-like Poets venerable made" — not Homer or Horace, as one might expect, but Denham and Cowley. ${ }^{146}$

This remarkable levelling between the evacuations of ancients and moderns is not open to everyone, however. While Shaftesbury "believed that human beings were naturally tasteful," and that soliloquy was a way "to get back to that original condition of purity," 147 Pope suggests in Peri Bathous that the quality of one's leavings have a deeper origin:

Farthermore, it were great Cruelty and Injustice, if all such Authors as cannot write in the other Way, were prohibited from writing at all. Against this, I draw an argument from what seems to an undoubted physical Maxim, That Poetry is a natural or morbid Secretion from the Brain. As I would not suddenly stop a Cold in the Head, or dry up my Neighbor's Issue, I would as little hinder him from necessary writing... I have known a Man thoughtful, melancholy, and raving for divers days, but forthwith grow wonderfully

\footnotetext{
${ }^{144}$ Claude Rawson, Swift and Others 96-101

${ }^{145}$ See David Morris, Pope: The Genius of Sense 60-64

146 Poems vol. 1 163-164.

147 See Denise Gigante, Taste 53
} 
easy, lightsome and cheerful, upon a Discharge of the peccant Humour, in exceeding purulent Metre... ${ }^{148}$

The facetiousness of Pope's parody is inescapable, but it contains within it two unique suggestions: that the build-up of worldly dregs simply happens, rather than being a product of consuming print waste, and that the "purulent Metre" of bad poets originates within their physiology.

While it is tempting to see this attribution of poor poetry to personal qualities as a simple farce on or even misreading of Addison, it largely coheres to the doctrine of the "Ruling Passion" expressed in the Epistle to Cobham:

Judge we by Nature? Habit can efface, Int'rest o'ercome, or Policy take place:

By Actions? those Uncertainty divides:

By Passions? these dissimulation hides:

Opinions? They still take a wider range:

Find, if you can, I what you cannot change.

Search then the Ruling Passion [...]

This clue once found, unravels all the rest ${ }^{149}$

Christopher Fox reads this idea of a singular, fixed, and impelling force as an "attempt to reconcile the two visions of the self" common in the early and mid-century, when debate between proponents of a traditional fixed identity and a shifting Lockean identity were at their

148 Alexander Pope, Major Works, ed. Pat Rogers (Oxford University Press, 2006) pp. 201-202. ${ }^{149}$ Poems vol. 3.2 168-176 
peak. ${ }^{150}$ In addition to this function, however, the doctrine of the Ruling Passion serves to prettify and soften the shocking cynicism of Peri Bathous's formulation of printed crudity as an immutable marker of a poor poet.

By defining his polite circle on terms of personal affection and inherent worthiness, Pope leaves room for the presence of individuals who, like the poor poets swarming the pages of the Epistle to Arbuthnot, "read [Pope] dead," remaining alienated and excluded from social education despite their consumption of good poetry. ${ }^{151}$ Under these regimes of inherent aesthetic poverty, people like Leonora the book-hoarder and the obsessive Valetudinarian posed little threat to the project of improvement - for although they purchase subscriptions as well as a good reader, they lack the heavenly "light" of "True Taste."152 In effect, Pope's poetic ideology promises the exact opposite of The Spectator project-not to improve the taste of the sick or find a place for the "butts" of polite society, but to separate (or evacuate) those of naturally poor qualities or debased ruling passions by pitting their verses against one another. Accepting as inevitable the Addisonian future of London as an appetite-driven consumer paradise, Pope instead seeks an Edenic enclave kept separate by careful critics, leaving the unworthy safely preserved "in the liquid Amber of... Wit" for the observation of the gawking masses. ${ }^{153}$

${ }^{150}$ Christopher Fox, Locke and the Scriblerians (Los Angeles: University of California Press, 1989) pp. 130-135

${ }^{151}$ Poems vol. 498

${ }^{152}$ Poems vol. 1240.

${ }^{153}$ Poems vol. 4108 n.169 
The Evacuated Share

As one proceeds further past Pope in the history of criticism, it becomes apparent that "theorizing in the taste mode was, alas, dying and being replaced" at the end of the eighteenthcentury, a victim of the burgeoning aesthetic theories of the nineteenth. ${ }^{154}$ In an ironic moment of nearly cosmic proportions, the Augustan taste theories themselves became waste products, so alien and disagreeable to later palettes that any possibility of repatriation fell flat. Addison's wit, his polite societies, and his conception of the imagination have all found ready recipients in the modern day — the theory of sense and discernment which lay under those ideas, broadly speaking, has not. We are left instead with the traces of those theories - the kind of strange subterranean logic of metaphor separated from its referents that leads to "matters of taste" as various as the gourmand culture of the Victorian era, or the persistent identification of teadrinking with the English identity. ${ }^{155}$

To those traces of taste I would propose to add another, equally persistent and dangerous in its vitality. Following the close of the eighteenth-century, the Augustan conceptions of printed waste continued to linger in popular writings, particularly where the burgeoning science of demography was concerned. Thomas Malthus was an avid reader of Alexander Pope, and cites the Essay on Man repeatedly throughout his Essay on Population. ${ }^{156}$ Is it yet conceivable that Pope's apocalyptic visions of endlessly reproducing hordes of "waste people" sowing the seeds of London's destruction may have had an impact on Malthus, who in his essay envisions a mass

${ }^{154}$ George Dickie, The Century of Taste 3-4

155 See Denise Gigante, Taste 160-180 on gourmand culture, as well as Charlotte Sussman, Consuming Anxieties 22-48 and David Porter, The Chinese Taste in Eighteenth-Century England 150-153 on tea culture.

156 Nine times, to be specific. See Robert Mayhew, New Perspectives on Malthus (Cambridge University Press, 2016) pp. 18 n. 2. 
of insufficiently productive poor who, in shirking the "great restrictive law" of restraint, spread "misery and vice" among themselves? ${ }^{157}$ Or that Malthus's notes on the paradoxical fertility of regions "laid waste" by war, fire and plague may have owed some inspiration to the "sable wastes" of Windsor-Forest, and the Miltonic paradise-in-ash behind it? ${ }^{158}$

The demographic implications of waste theory need not be confined to the nineteenthcentury. Claude Rawson has already noted the extent to which Oscar Wilde and George Bernard Shaw's twentieth-century "vocabulary of punitive isolation," whereby innocuous statements on the benefits of social programs were phrased in stark terms of "looking forward to the extermination of the poor," stand in rhetorical continuity with Swift's descriptions of the Yahoos and "wild Irish." 159 There is a similar vocabulary at work in all Augustan writing on printed waste and its writers, who are inevitably configured as compulsive scribblers, public urinaters, and sweating syphilitics. They are, in other words, "waste people," and that designation carries with it an ideological imperative for evacuation by one means or another.

These traces of eighteenth-century taste have persisted in the form of waste discourse because they address questions relevant in our era - to what extent can individual discernment be trusted? And if some number of people are incapable of distinguishing waste from salvageable matter, what reactions does the presence of that waste justify? These are valid concerns, but the

157 Thomas Malthus, An Essay on the Principle of Population, ed. Donald Winch (Cambridge University Press, 1992) 14. Note also that in Malthus's vision the impoverished classes, like Pope's Dunces, reproduce "not so much from malice... as from Dulness, and not so much from Dulness, as necessity" - or even, as Malthus frames it, from an admirable and almost holy sense of love (Essay 64-65).

${ }^{158}$ Essay 35. See also Book 3 of Paradise Lost 334-337:

The World shall burn,and from her ashes spring

New Heav'n and Earth, wherein the just shall dwell

And after all thir tribulations long

See golden days, fruitful of golden deeds,

${ }^{159}$ See Claude Rawson, God, Gulliver, and Genocide 183-256 
rhetorical tropes with which the Augustan waste theorists have taken on disturbing implications in light of later history, as the stakes of discussing the perpetually generative wasteland of popular culture in the Addisonian idiom of disease or in the cadence of Swiftian desperation for a solution have become apparent. More insidious still is the nostalgic, pre-lapsarian paradise between Windsor-Forest and The Dunciad, which slips almost imperceptibly from praising waste-free poetry to soliciting the elect to preserve it by relegating alien voices to the footnotes. In each case, it is worth remembering that the books which I have been cavalierly referring to as "print waste" are not merely "dead things," but the "season'd lives" of those who have written them. 
Bibliography

Addison, Joseph. “A Dialogue upon the Usefuleness of Ancient Medals.” In The Works of Joseph Addison, 3:273-80. New York: Harper and Brothers, 1864.

De La Fontaine, Jean. Fables. Translated by Norman Shapiro. Champaign: University of Illinois Press, 2007.

Malthus, Thomas. An Essay on the Principle of Population. Edited by Donald Winch. Cambridge University Press, 1992.

Milton, John. “Areopagitica.” In Complete Poems and Major Prose, edited by Merritt Hughes, 716-49. Indianapolis: Hackett, 1957.

Pope, Alexander. Poems of Alexander Pope. Edited by John Butt.11 vols. London: Methuen, 1961.

—Vol. 1, "Pastoral Poetry and an Essay on Criticism.” Edited by E. Audra and Aubrey Williams.

—Vol. 3.1, “An Essay on Man.” Edited by Maynard Mack.

—Vol. 3.2, "Epistles to Several Persons (Moral Essays).” Edited by F.W. Bateson.

—Vol. 4, "Imitations of Horace and An Epistle to Dr. Arbuthnot and The Epilogue to the Satires.” Edited by John Butt.

—Vol. 5, “The Dunciad.” Edited by James Sutherland

Pope, Alexander. The Rape of the Lock. Edited by Cynthia Wall. Boston: Bedford, 1997.

Pope, Alexander. Major Works. Edited by Pat Rogers. Oxford University Press, 2006.

Shaftesbury, Anthony Ashley Cooper. Soliloquy, or, Advice to an Author. London: Printed for John Morphew, 1710. 
Swift, Jonathan. The Prose Works. Edited by Herbert Davis. Vol. 7. 14 vols. Oxford: Basil Blackwell, 1939.

Swift, Jonathan. Gulliver's Travels. Edited by Albert Rivero. New York: Norton, 2002.

Swift, Jonathan. The Tale of the Tub. Edited by Angus Ross and David Woolley. Oxford University Press, 2008.

The Spectator. Edited by Donald Bond. Oxford: Clarendon, 1965.

Bataille, Georges. The Accursed Share: An Essay on General Economy, Vol. 1: Consumption. Translated by Robert Hurley. Cambridge: Zone Books, 1991.

Billig, Michael. Laughter and Ridicule. Thousand Oaks: SAGE, 2005.

Blair, Ann. Too Much to Know. New Haven: Yale University Press, 2010.

Bourdieu, Pierre. Distinction. Translated by Richard Nice. Cambridge: Harvard University Press, 1984.

Brewer, John. The Pleasures of the Imagination. Abingdon: Routledge, 2013.

Brown, Laura. Ends of Empire. Ithaca: Cornell University Press, 1993.

Brown, Tony. The Primitive, the Aesthetic, and the Savage. Minneapolis: University of Minnesota, 2012.

Castle, Terry. "Why the Houyhnhnms Don't Write: Swift, Satire, and the Fear of Text." Essays in Literature 7, no. 1 (1980): 31-44.

Cleary, Scott. "Slouching toward Augusta: Alexander Pope's 1736 'Windsor Forest." Studies in English Literature 50, no. 3 (Summer 2010): 645-63.

Clifford, James. "Gulliver's Fourth Voyage: Hard and Soft Schools of Interpretation.” In Quick Springs of Sense, edited by Larry Champion. Athens: University of Georgia Press, 2011. 
Costelloe, Timothy. The British Aesthetic Tradition. Cambridge University Press, 2013.

Damrosch, Leopold. The Imaginative World of Alexander Pope. Los Angeles: University of California Press, 1987.

Dickie, George. The Century of Taste. Oxford University Press, 1996.

Eagleton, Terry. The Ideology of the Aesthetic. Oxford: Blackwell, 1990.

Erskine-Hill, Howard. "Pope and Slavery.” In Alexander Pope: World and Word. London: British Academy, 1997.

Erskine-Hill, Howard, ed. Selected Letters of Alexander Pope. Oxford University Press, 2000.

Eugenia, Jenkins. "'Nature to Advantage Drest': Chinoiserie, Aesthetic Form, and the Poetry of Subjectivity in Pope and Swift.” Eighteenth-Century Studies 43, no. 1 (Fall 2009).

Fabricant, Carole. "Aesthetics and the Politics of Landscape." In Studies in Eighteenth-Century British Art and Aesthetics, edited by Ralph Cohen. Los Angeles: University of California Press, 1985.

Fox, Christopher. Locke and the Scriblerians. Los Angeles: University of California Press, 1989.

Gee, Sophie. Making Waste. Princeton University Press, 2010.

Gee, Sophie. “'Such Opinions Cannot Cohere': Swift's Inwardness.” Republics of Letters 4, no. 1 (October 2014).

Gigante, Denise. Taste. New Haven: Yale University Press, 2005.

Gikandi, Simon. Slavery and the Culture of Taste. Princeton University Press, 2014.

Griffin, Dustin. Pope and Swift. Cambridge University Press, 2010.

Hammond, Eugene. Jonathan Swift: Our Dean. Newark: University of Delaware Press, 2016.

Hunter, Paul. Before Novels. Cambridge University Press, 2015. 
Johnson, Erik L. “'Life Beyond Life’: Reading Milton’s Areopagitica through Enlightenment Vitalism.” Eighteenth-Century Studies 49, no. 3 (Spring 2016): 353-70.

Knight, Charles. A Political Biography of Richard Steele. London: Pickering \& Chatto, 2014.

Lynall, Gregory. Swift and Science. New York: Palgrave, 2012.

Lynch, Deidre. “'Wedded to Books': Bibilomania and the Romantic Essayists.” Romantic Circles Praxis Series Romantic Libraries (2004).

Mayhew, Robert. New Perspectives on Malthus. Cambridge University Press, 2016.

McKeon, Michael. The Secret History of Domesticity. Baltimore: Johns Hopkins University Press, 2006.

Morris, David. Pope: The Genius of Sense. Cambridge: Harvard University Press, 1984.

Noggle, James. The Temporality of Taste. Oxford University Press, 2012.

Ormsby-Lennon, Hugh. Hey Presto! Newark: University of Delaware Press, 2011.

Pasanek, Brad. Metaphors of Mind. Baltimore: Johns Hopkins University Press, 2015.

Pincus, Steve. "Addison's Empire: Whig Conceptions of Empire in the Early 18th Century." Parliamentary History 31, no. 1 (February 2012): 99-117.

Porter, David. The Chinese Taste in Eighteenth-Century Taste. Cambridge University Press, 2014.

Porter, Roy. Flesh in the Age of Reason. New York: Norton, 2005.

Power, Henry. Epic Into Novel. Oxford University Press, 2015.

Price, Martin. To the Palace of Wisdom. Carbondale: Southern Illinois University Press, 1970. Raven, James. "Debating Bibliomania and the Collection of Books in the Eighteenth Century." Library and Information History 29, no. 3 (2013): 196-209. 
Raven, James. Publishing Business in Eighteenth-Century England. Suffolk: Boydell and Brewer, 2014.

Rawson, Claude. God, Gulliver, and Genocide. Oxford University Press, 2001.

Rawson, Claude. Swift's Angers. Cambridge University Press, 2014.

Rawson, Claude. Swift and Others. Cambridge University Press, 2015.

Richardson, John. “Alexander Pope's 'Windsor Forest': Its Context and Attitudes towards Slavery." Eighteenth-Century Studies 35, no. 1 (Fall 2001): 1-17.

Rogers, Pat. Grub Street: Studies in a Subculture. London: Methuen, 1972.

Sams, Henry. Swift and Steele as Partisan Writers. Pennsylvania State University Press, 1967.

Silver, Sean. The Mind Is a Collection. New Haven: Yale University Press, 2015.

Sitter, John. Arguments of Augustan Wit. Cambridge University Press, 1991.

Staves, Susan. “Pope's Refinement.” The Eighteenth Century 29, no. 2 (Spring 1988): 145-63.

Sussman, Charlotte. Consuming Anxieties. Stanford University Press, 2000.

Tsien, Jennifer. The Bad Taste of Others. Cambridge University Press, 2014.

Williams, Abigail. Poetry and the Creation of a Whig Literary Culture 1681-1714. Oxford University Press, 2005. 